\title{
EFFECTIVENESS COMPARATIVE OF SCIENTIFIC APPROACH ELPSA AND OPEN-ENDED SETTING COOPERATIVE STAD TYPES OF MATHEMATICS LEARNING AT VII CLASS SMP NEGERI OF A ACCREDITATION IN MAKASSAR
}

\author{
Andi Kaharuddin ${ }^{1)}$ \\ ${ }^{1}$ SMP Negeri 6 Makassar, Makassar, Indonesia \\ e-mail : Andikaharuddinppsunm@gmail.com
}

\begin{abstract}
This study aimed to: (1) describe the effectiveness of the Scientific learning approach setting cooperative STAD Types in mathematics learning at students of class VII SMP Negeri of A-Accreditation in Makassar; (2) describe the effectiveness of ELPSA learning approach setting cooperative STAD type in mathematics learning at students of class VII SMP Negeri of A-Accreditation in Makassar; (3) describe the effectiveness of Open-Ended learning approach setting cooperative STAD type in mathematics learning at students of class VII SMP Negeri of A-Accreditation in Makassar; (4) describe comparative effectiveness of Scientific learning approach, ELPSA and Open-Ended Setting Cooperative STAD Types of Mathematics Learning at Students of class VII SMP Negeri of A-Accreditation in Makassar. The population in this research were all of students at class VII SMP Negeri of A-Accreditation in Makassar and the sample consisted that selected by using a cluster stratified random sampling technique. The result of $t$ test on the level of significant $\alpha=0.025$ at the major hypothesis (1) the implementation of the Scientific approach is effective (2) the implementation of the ELPSA approach is effective, (3) the implementation of the Open-Ended approach is effective, and the result of anova test on the level of significant $\alpha=0.05$ at the major (4) to (a) learning outcomes (posttest, gain) (b) interest in learning (c) response, the result of equality two proportions test there is no differences implementation in Scientific approach application, ELPSA and Open-Ended Setting Cooperative STAD Types in mathematics learning at students of class VII SMP Negeri of A-Accreditation in Makassar.
\end{abstract}

Keywords: Comparison, Scientific Aprroach; ELPSA Approach; Open-Ended setting cooperative and effectiveness

\section{PENDAHULUAN}

Matematika merupakan pengetahuan yang sangat penting dalam kehidupan manusia. Disadari atau tidak, dalam kehidupan sehari-hari setiap individu sering menggunakan matematika dalam menjalankan aktifitasnya. Dalam kaitannya pembelajaran matematika disekolah, ada persepsi umum yang sudah berakar dalam dunia pendidikan yang juga sudah menjadi harapan masyarakat. Persepsi umum ini menganggap bahwa sudah merupakan tugas guru untuk mengajar dan menyodori siswa dengan muatan muatan informasi dan pengetahuan perkembangan ilmu pengetahuan dan teknologi memungkinkan semua pihak dapat memperoleh informasi yang cepat dan mudah dari berbagai sumber. Dengan demikian siswa perlu memiliki kemampuan memperoleh, memilih, dan mengelola informasi untuk bertahan pada keadaan 
yang selalu berubah, tidak pasti, dan kompetitif. Kemampuan ini membutuhkan pemikiran kritis, sistematis, logis, kreatif, dan kemauan bekerjasama yang efektif. Cara berfikir seperti ini dapat dikembangkan melalui belajar matematika, karena matematika memiliki struktur dan keterkaitan yang kuat dan jelas antar konsepnya sehingga memungkinkan kita terampil berpikir rasional. Oleh karena pentingnya peranan matematika, maka pengajaran matematika di berbagai jenjang pendidikan formal perlu mendapat perhatian dan penanganan yang serius. Seperti yang dikatakan Akib (2016) bahwa tujuan mengajar matematika tidak hanya bergantung pada tujuan kognitif, tetapi juga di tujuan afektif, sehingga dalam mengajar matematika, siswa tidak hanya diharapkan memiliki intelektual, tetapi juga diharapkan memiliki sikap terpuji kejujuran, akurasi dan sikap afektif lainnya.

Para siswa di berbagai jenjang pendidikan termasuk di sekolah menengah mutlak dituntut untuk menguasai pelajaran matematika. Bahkan lebih dari itu, siswa diharapkan memiliki hasil belajar matematika yang tinggi. Namun kenyataan dilapangan pada saat wawancara langsung tanggal 2 agustus 2016 dan wawancara via telfon tanggal 19 agustus 2016 dengan beberapa guru disekolah SMP yang terakreditasi A di Kota Makassar, penggunaan model atau pendekatan disekolah sudah diterapkan semenjak kurikulum 2013, tetapi terdapat sebagian SMP Akreditasi A di Kota Makassar terkadang menerapkan pembelajaran konvensional atau pembelajaran yang berpusat pada guru dikarenakan guru merasa jenuh dengan pendekatan yang sering bergonta-ganti. Akibatnya siswa menjadi pasif dan diposisikan sebagai objek yang hanya menunggu dan menyerap informasi dari guru. Hal ini dapat dilihat dari skor rata-rata hasil belajar ulangan harian mata pelajaran matematika siswa 2016-2017 adalah 71 dari skor ideal 100 . Rata-rata hasil belajar siswa memang tinggi namun, variansi atau penyebaran kemampuan siswa berbeda, itu dapat dilihat dari nilai hasil belajar ulangan harian mata pelajaran matematika siswa, hasil belajar siswa ada yang tinggi dan ada yang rendah sekali. Seperti yang dikatakan Nasiruddin, dkk (2012) bahwa banyak faktor yang mempengaruhi hasil belajar siswa diantaranya adalah guru dan metode pembelajaran yang digunakan. Sampai saat ini masih banyak guru hanya menyampaikan pengetahuan kepada peserta didik dan peserta didik hanya menerima apa yang disampaikan guru sehingga mereka cenderung pasif dan pembelajaran menjadi membosankan. Nisbet (1985: 43) mengatakan tidak ada cara tunggal yang tepat untuk belajar dan tak ada cara terbaik untuk mengajar. Namun demikian seorang guru dapat menerapkan salah satu model atau pendekatan yang cocok dengan

mempertimbangkan kondisi siswa. Kemudian Cheriani, dkk (2015: 1) mengatakan bahwa guru sebagai pendidik dalam hal ini harus mampu menerapkan model yang dapat mengintegrasikan karakter rasa ingin tahu yang 
tinggi (eksplorasi), kreatif, kritis, berani mencoba, yakin bisa melakukan (selfefficacy), jujur, bertanggung jawab untuk tugas, kerjasama, disiplin, kerja keras, mampu mengorganisir diri, bekerja sama dengan orang lain. Sejalan dengan pendapat diatas, siswa diharapkan mampu mengkonstruksi pemahamannya sendiri menurut diri mereka sendiri. Karenanya peranan guru cenderung sebagai fasilitator ketimbang penyedia informasi. Salah satu upaya agar siswa aktif dan dapat berhasil yaitu dengan cara menerapkan model pembelajaran bermakna yang berpusat pada siswa (student centered) diantaranya model pembelajaran kooperatif tipe STAD, model pembelajaran kooperatif tipe STAD yaitu suatu model pembelajaran yang mengedepankan aktivitas siswa dalam mencari, mengelola, bekerjasama dan melaporkan informasi dari berbagai sumber yang akhirnya mempertanggung jawabkan secara individual terhadap pemahaman mereka melalui kuis yang diberikan oleh guru. Seperti dijelaskan Nurhidayah, dkk $(2015,94)$ adanya interaksi antar peserta didik selama proses pembelajaran kelompok, saling bertukar pikiran serta saling membantu dalam menyelesaikan masalah akan menumbuhkan rasa percaya diri dan semangat peserta didik dalam belajar matematika yang akan menyebabkan motivasi belajar matematika dapat meningkat.

Pendekatan Saintifik sesuai dengan tujuan kurikulum 2013 untuk membantu siswa dalam memahami pelajaran. Secara khusus dalam mengajarkan matematika, guru harus mampu mengaitkan pembelajaran dengan situasi lingkungan siswa sebab hal tersebut dapat membantu siswa untuk lebih memahami konsep yang diajarkan. Sesuai dengan penilitian Ningsih (2015) menunjukkan bahwa terdapat pengaruh pembelajaran Saintifik setting kooperatif tipe STAD terhadap hasil belajar siswa, aktivitas siswa dan respons siswa dalam pembelajaran matematika kelas VII SMP negeri 6 watampone. Ini berarti pendekatan Saintifik dapat mempengaruhi peningkatkan hasil belajar, aktivitas, dan respons siswa terhadap pembelajaran. Hal ini senada dengan pendapat Van de Henvel-Panhuizen (dalam Ningsih, 2015), mengungkapkan bahwa "Bila anak belajar matematika terpisah dari pengalaman mereka sehari-hari, maka anak akan cepat lupa dan tidak dapat mengaplikasikan matematika."

Pendekatan ELPSA merupakan sebuah kerangka desain pembelajaran yang dibuat secara khusus untuk konteks Indonesia sebagai hasil dari analisis data video TIMSS (Thrends International Mathematics Science Study) (Lowrie \& Patahudin, 2015: 95). Dalam kegiatan pengenalan kerangka pembelajaran ELPSA yang disampaikan oleh Prof. Tom Lowrie dari Charles Sturt University, Australia dan Dr. Sitti Maesuri Patahuddin kerangka pembelajaran ELPSA pertama kali digunakan dalam mendesain pembelajaran matematika Geometri untuk guru Matematika SMP yang digunakan dalam forum MGMP. Pembelajaran ELPSA (Experiences, Language, Pictorial, Symbol, Application) dikembangkan berdasarkan pada teori pembelajaran konstruktivisme dan bersifat sosial. Sesuai dengan penelitian Syarifuddin (2016) tentang keefektifan 
pendekatan ELPSA dengan setting kooperatif dalam pembelajaran matematika materi bangun ruang sisi datar pada kelas VIII SMP negeri 4 binamu kabupaten jeneponto. Hasil penelitian menunjukkan bahwa pendekatan ELPSA dapat meningkatkan kualitas pembelajaran dengan melihat dari indikator keefektifan penerapan pembelajaran ELPSA.

Pendekatan Open-Ended merupakan salah satu upaya inovasi pendidikan matematika yang pertama kali dilakukan oleh para ahli pendidikan matematika Jepang. Pendekatan ini lahir sekitar dua puluh tahun yang lalu dari hasil penelitian yang dilakukan Shigeru Shimada, Toshio Sawada, Yoshiko Yashimoto, dan Kenichi Shibuya (dalam Afgani, 2014). Pemberian tugas matematika rutin yang diberikan pada latihan atau tugas-tugas matematika selalu terfokus pada prosedur dan keakuratan, jarang sekali tugas matematika terintegrasi dengan konsep lain dan juga jarang memuat soal yang memerlukan kemampuan berfikir tingkat tinggi. Seperti halnya penelitian Nurlidia (2015) tentang komparasi keefektifan pendekatan Saintifik, problem solving dan OpenEnded setting discovery learning dalam pembelajaran matematika materi lingkaran di kelas VIII SMP Negeri 2 Sinjai Timur. Hasil penelitian menunjukkan bahwa dengan pendekatan Open-Ended tugas dari pembelajaran matematika dapat meningkat ditinjau dari indikator keefektifan penerapan pendekatan Open-Ended dari penelitian tersebut.

Berdasarkan latar belakang diatas, maka rumusan masalah dalam penelitian ini adalah: (1) Apakah penerapan pendekatan Saintifik setting kooperatif tipe STAD efektif dalam pembelajaran matematika pada kelas VII SMP Negeri Akreditasi A di Kota Makassar?; (2) Apakah penerapan pendekatan ELPSA setting kooperatif tipe STAD efektif dalam pembelajaran matematika pada kelas VII SMP Negeri Akreditasi A di Kota Makassar?; (3) Apakah penerapan pendekatan Open-Ended setting kooperatif tipe STAD efektif dalam pembelajaran matematika pada kelas VII SMP Negeri Akreditasi A di Kota Makassar?; (4) Apakah terdapat perbedaan keefektifan pendekatan ELPSA, Saintifik dan Open-Ended setting kooperatif tipe STAD dalam pembelajaran matematika pada kelas VII SMP Negeri Akreditasi A di Kota Makassar?

\section{METODE PENELITIAN}

Penelitian ini mengkomparasikan keefektifan penerapan pendekatan Saintifik, ELPSA dan Open-Ended setting Kooperatif Tipe STAD pada kelas VII SMP Negeri Akreditasi A di Kota Makassar. Karena ada perlakuan (treatment), sehingga penelitian ini digolongkan ke dalam penelitian eksperimen. Dengan demikian metode penelitian eksperimen dapat diartikan sebagai metode penelitian yang digunakan untuk mencari pengaruh perlakuan tertentu terhadap yang lain dalam kondisi yang terkendali (Sugiyono, 
2013: 107).

\section{Desain Penelitian}

Desain Penelitian ini adalah randomized pretest-posttest comparison group design. Pemilihan desain ini dengan mempertimbangkan bahwa dalam rancangan penelitian yang dilaksanakan diawali dengan pretest sebelum perlakuan diberikan. Adapun desain penelitiannya dapat dilihat pada Tabel 2.1

Tabel 2.1 Desain Penelitian

\begin{tabular}{|c|c|c|c|c|}
\hline Metode & Sekola & Pretest & Treatment & Posttest \\
\hline & SMP Negeri 26 & $\mathrm{O}$ & $\mathrm{X}$ & $\mathrm{O}$ \\
\hline $\mathrm{R}$ & $\begin{array}{c}\text { Makassar } \\
\text { SMPN 16 Makassar }\end{array}$ & $\begin{array}{l}1 \\
\mathrm{O} 2\end{array}$ & $\begin{array}{c}1 \\
X_{3}\end{array}$ & $\begin{array}{c}4 \\
\text { O6 }\end{array}$ \\
\hline
\end{tabular}

\section{Populasi dan Sampel}

Populasi dalam penelitian adalah siswa kelas VII SMP Akreditasi A Kota Makassar tahun pelajaran 2016/2017 yang terdiri dari 31 sekolah SMP. Sampel penelitian terdiri dari tiga kelas dari sekolah yang berbeda yang diberikan perlakuan dengan menggunakan pendekatan Saintifik, ELPSA dan Open-Ended.

\section{HASIL PENELITIAN DAN PEMBAHASAN}

\section{Hasil Penelitian}

(1) Keterlaksanaan pendekatan pembelajaran Saintifik setting Kooperatif Tipe STAD

Berdasarkan hasil observasi dari dua orang observer terhadap keterlaksanaan pembelajaran yang menerapkan pendekatan Saintifik setting Kooperatif Tipe STAD diperoleh data keterlaksanaan seperti yang tercantum pada Tabel 3.1 berikut ini.

Tabel 3.1 Keterlaksanaan Pendekatan Pembelajaran Saintifik Setting Kooperatif Tipe STAD

\begin{tabular}{ccc}
\hline Pertemuan & Skor rata-rata & Kategor \\
\hline I & 2,9 & Terlaksana dengan Baik \\
I & 2,9 & Terlaksana dengan Baik \\
II & 3,0 & Terlaksana dengan sangat Baik \\
\hline Rata-rata & 2,9 & Terlaksana dengan Baik \\
\hline
\end{tabular}

\section{(2) Keterlaksanaan pendekatan pembelajaran ELPSA setting Kooperatif} Tipe STAD

Berdasarkan hasil observasi dari dua orang observer terhadap keterlaksanaan pembelajaran yang menerapkan pendekatan ELPAS setting Kooperatif Tipe STAD diperoleh data keterlaksanaan seperti yang tercantum pada Tabel 3.2 berikut ini. 
Tabel 3.2 Keterlaksanaan Pendekatan Pembelajaran ELPSA Setting Kooperatif Tipe STAD

\begin{tabular}{ccc}
\hline Pertemuan & Skor rata-rata & Kategor \\
\hline I & 2,7 & Terlaksana dengan Baik \\
I & 3,0 & Terlaksana dengan Baik \\
II & 3,2 & Terlaksana dengan sangat Baik \\
\hline Rata-rata & 2,9 & Terlaksana dengan Baik \\
\hline
\end{tabular}

(3) Keterlaksanaan pendekatan pembelajaran ELPSA setting Kooperatif Tipe STAD

Berdasarkan hasil observasi dari dua orang observer terhadap keterlaksanaan pembelajaran yang menerapkan pendekatan Open-Ended setting Kooperatif Tipe STAD diperoleh data keterlaksanaan seperti yang tercantum pada Tabel 3.3 berikut ini

Tabel 3.3 Keterlaksanaan Pendekatan Pembelajaran ELPSA Setting Kooperatif Tipe STAD

\begin{tabular}{ccc}
\hline Pertemuan & Skor rata-rata & Kategor \\
\hline I & 3,2 & Terlaksana dengan Sangat Baik \\
I & 3,8 & Terlaksana dengan Baik \\
II & 3,2 & Terlaksana dengan sangat Baik \\
\hline Rata-rata & 3,1 & Terlaksana dengan Sangat Baik \\
\hline
\end{tabular}

\section{(4) Hasil analisis keefektifan pembelajaran Penerapan pendekatan Saintifik}

Berdasarkan nilai hasil belajar matematika siswa kelasnVII SMP Negeri 26 Makassar (SMP Negeri Akreditasi A di Kota Makassar) detpelah diterapkan pendekatan Saintifik setting kooperatif tipe STAD menunjukkan persentase ketuntasan siswa secara klasikal mencapai $85 \%$, artinya keturtałan hasil beldjat secara klasikal tercapai. Skor rata-rata posttest siswa setelah diajar lebih besar dari 75 (KKM) yaitu 77,60. Selain itu, nilai rata-rata gain ternormalisasi siswa sebesar 0,38 yang berada pada kategori sedang. Skor rata-rata aktivitas siswa pada penerapan pendekatan Saintifik setting kooperatif tipe STAD sebesar 3,2 termasuk dalam kategori baik, Skor rata-rata minat belajar siswa pada penerapan pendekatan Saintifik setting kooperatif tipe STAD sebesar 2,6 termasuk dalam kategori tinggi. Skor rata-rata respon siswa terhadap penerapan pendekatan Saintifik setting kooperatif tipe STAD adalah 3,0 atau berada dalam kategori cenderung positif, Sehingga dapat disimpulkan secara deskriptif bahwa penerapan pendekatan Saintifik setting kooperatif tipe STAD efektif ditinjau dari hasil belajar, aktivitas, minat dan respons. Berdasarkan nilai posttest roleh nilai st $\mathrm{k} t=2,925 \mathrm{~d}$ nilai $p=0$, karena nilai $p<$ dari $\alpha=0,025$ maka i tolak dan terima, gain roleh nilai s ik $t=14,885$ dan nilai $p=0,000$, karena nilai $p<$ 
dari $\alpha=0,025$ maka i tolak dan terima dengan perkataan lain untuk tingkat kepercayaan 95\% rata-rata nilai posttest setelah diterapkan pendekatan Saintifik setting Kooperatif Tipe STAebih besar dar da 74,9. Ketuntasan klasikal uji proporsi/uji $z$ dengan menggunakan taraf signifikan $5 \%$ di perol eh $Z$ hitung $=0$, dan $Z$ tabel $=4$ karena $Z$ hitung $<Z$ tabel maka di terima dan tolak, minat bela diperoleh nil tistik $t=2,853$ dan nilai $p=0$ karena nilai $p$ dari $\alpha=0,025$ maka di tolak dan terima, respons diperoleh nilai istik $t=8,356$ nilai $p=0,000$, karena nilai $p<$ dari $\alpha=0,025$ maka di tolak dan terima, Sehingga dapat disimpulkan secara inferensial bahwa penerapan pendekatan Saintifik setting kooperatif tipe STAD efektif ditinjau dari posttest, gain, ketuntasan klasikal, minat dan respons.

\section{Penerapan pendekatan ELPSA}

Hasil belajar matematika siswa kelas VII SMPN 5 Makassar (SMP Negeri Akreditasi A di Kota Makassar) setelah diterapkan pendekatan Saintifik setting kooperatif tipe STAD menunjukkan persentase ketuntasan siswa secara klasikal mencapai $88 \%$, artinya ketuntasan hasil belajar secara klasikal tercapai. Skor rata-rata posttest siswa setelah diajar lebih besar dari 75 (KKM) yaitu 81,20. Selain itu, nilai rata-rata gain ternormalisasi siswa sebesar 0,49 yang berada pada kategori sedang.. Skor rata-rata aktivitas siswa pada penerapan pendekatan ELPSA setting kooperatif tipe STAD sebesar 3,4 termasuk dalam kategori baik, Skor rata-rata minat belajar siswa pada penerapan pendekatan ELPSA setting kooperatif tipe STAD sebesar 2,9 termasuk dalam kategori tinggi. Skor rata-rata respon siswa terhadap penerapan pendekatan ELPSA setting kooperatif tipe STAD adalah 3,1 atau deqreda dalam kattexgori cenderung positif, Sehingga dapat disimpulkan secara deskriptif bahwa penerapan pendekatan ELPSA setting kooperatif tipe STAD efektif ditinjau dari hasil belajar, aktivitas, minat dan respo Berdasdr, nilai posttest roleh nila(0), $\mathrm{k} t=2,935$ lahnilai $p=0,000$ karena nilai $p_{\text {ai }} \leq$ dari $\alpha=0,025$ maka i tolak dan terima, gain dip roleh nilai tat ik $t=$ 10,204 dan nilai $p=0,000$, karena nilai $p<$ dari $\alpha=0,025$ makai tolak dan

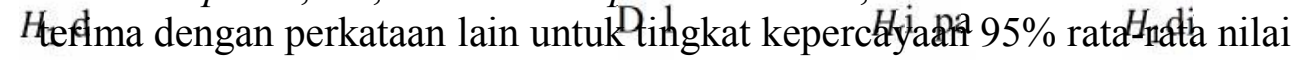
posttest setelah diterapkan pendekatan Sainsific setting Kpeparatif Tipe $\cdot$ STA ebih besar dar da 74,9. Ketuntasan klasikal uji proporsi/uji $z$ dengan menggunakan taraf signifikan $5 \%$ di eh $Z$ hitung $=0$, dan $Z$ tabel $=4$ karena $Z$ hitung $<Z$ tabel makadi terima dan tolak, minat bela 'diperoleh nil tistik $t=$ 9,645 dan nilai $p=0$ karena nilai $p$ darita $\alpha=0,025$ maka di tolak dan terima, respons diperoleh nilai statistik $t=8,759$ nilai $p=0,000$, karena nilai $p<$ dari $\alpha=0,025$ maka di tolak dan terihra, Sehingga defpat disimpulkan secara inferensial bahwa penerapan pendekatan Saintifik setting kooperatif tipe STAD efektif ditinjau dari posttest, gain, ketuntasan klasikal, minat dan respons. 


\section{Penerapan pendekatan Open-Ended}

Hasil belajar matematika siswa kelas VII SMPN 16 Makassar (SMP Negeri Akreditasi A di Kota Makassar) setelah diterapkan pendekatan Saintifik setting kooperatif tipe STAD menunjukkan persentase ketuntasan siswa secara klasikal mencapai $88 \%$, artinya ketuntasan hasil belajar secara klasikal tercapai. Skor rata-rata posttest siswa setelah diajar lebih besar dari 75 (KKM) yaitu 81,45. Selain itu, nilai rata-rata gain ternormalisasi siswa sebesar 0,41 yang berada pada kategori sedang.. Skor rata-rata aktivitas siswa pada penerapan pendekatan ELPSA setting kooperatif tipe STAD sebesar 3,4 termasuk dalam kategori baik, Skor rata-rata minat belajar siswa pada penerapan pendekatan ELPSA setting kooperatif tipe STAD sebesar 3,0 termasuk dalam kategori tinggi. Skor rata-rata respon siswa terhadap penerapan pendekatan ELPSA setting kooperatif tipe STAD adalah 3,0 atau berada dalam kategori cenderung positif, Sehingga dapat disimpulkan secara deskriptif bahwa penerapan pendekatan ELPSA setting kooperatif tipe STAD efektif ditinjau dari hasil belajar, aktivitas, minat dan res. a

Berdabadkan nilai postte peroleh nil tideil $t=673$ dan piłai $0,003=$ karena

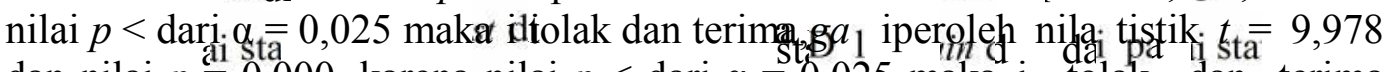
dan nilai $p \stackrel{a 1}{=} 0,000$, karena nilai $p<$ dari $\alpha=0,025$ maka $i$ tolak dan terima

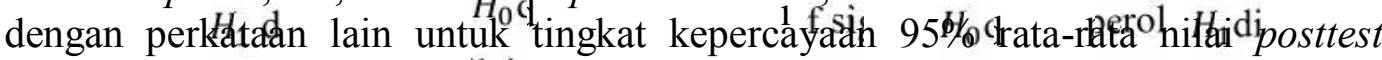
setelah diterapkan pendekatan Saintifik setting Kooperatif Tip\& $\mathbb{i}_{i}$ STA lebih besar dar da 74,9. Ketuntasan klasikal uji proporsi/uji $z$ dengan menggunakan tara gnifikan 5\% dieh $Z$ hitung $=0$, dan $Z$ tabel $=4$ karena $Z$ hitung $<Z$ tabel maka di terima dan tolak, minat bela diperolethanil tistik $t=1$ 3) 420 dan nilai $p=$ 0 , karena nilai dari $\alpha=0,025$ maka di tolak $H_{0}$ da terima, resp $q_{1} s_{\mathrm{d}}$ diperoleh nilai istik $t=5,581$ nilai $p=0,000$, karena nilai $p \stackrel{H_{0}}{\leftarrow}$ dari $\alpha=0,025$ maka ditolak dan terima, Sehingga dapat disimpulkan secara inferensial bahwa penerapan pendekatan Saintifik setting kooperatif tipe STAD efektif ditinjau dari posttest, gain, ketuntasan klasikal, minat dan respons.

\section{Komparasi keefektifan secara deskriptif Hasil belajar}

Komparasi skor hasil belajar siswa ditentukan dengan membandingkan rata-rata posttest, gain ternormalisasi dan persentase ketuntasan secara klasikal sebagai berikut.

Tabel 3.4. Komparasi Indikator Hasil Belajar Secara Holistik Untuk Pendekatan Pembelajaran Secara Deskriptif

\begin{tabular}{ccccccc}
\hline Penerapan & Kelas & pretest & posttest & Gain & KK & Rata-rata \\
\hline Saintifik & Eksperimen I & 42,8 & 77,6 & 0,60 & 85 & 2,7 \\
ELPSA & Eksperimen & 42,6 & 81,2 & 0,67 & 88 & 2,9 \\
Open-Ended & Eksperimen & 39,5 & 81,0 & 0,64 & 87 & 2,8 \\
\hline
\end{tabular}

\section{Aktivitas}


Komparasi aktivitas siswa ditentukan berdasarkan skor rata-rata aspek observasi pada masing-masing kelas pada kelompok sebagaimana tampak pada tabel berikut.

Tabel 3.5. Komparasi Aktivitas Untuk Pendekatan Pembelajaran Secara Deskriptif

\begin{tabular}{cccc}
\hline Pendekatan & Kelas & Skor Rata-Rata Total & Kategori \\
\hline Saintifik & Eksperimen I & 3,2 & Baik \\
ELPSA & Eksperimen II & 3,4 & Baik \\
Open-Ended & Eksperimen & 3,4 & Baik \\
\hline
\end{tabular}

\section{Minat Belajar}

Komparasi minat belajar siswa ditentukan berdasarkan skor rata-rata minat belajar siswa pada masing-masing kelas sebagaimana tampak pada tabel berikut.

Tabel 3.6. Komparasi Minat Belajar Siswa Untuk Pendekatan Pembelajaran Secara Deskriptif

\begin{tabular}{cccc}
\hline Pendekatan & Kelas & Skor Rata-Rata Total & Kategori \\
\hline Saintifik & Eksperimen I & 2,6 & Tinggi \\
ELPSA & Eksperimen II & 2,9 & Tinggi \\
Open-Ended & Eksperimen III & 3,0 & Tinggi \\
\hline
\end{tabular}

\section{Respons}

Komparasi respons siswa ditentukan berdasarkan skor rata-rata respons siswa pada masing-masing kelas sebagaimana tampak pada tabel berikut.

Tabel 3.7. Komparasi Respons Siswa Terhadap Pendekatan Pembelajaran Secara Deskriptif

\begin{tabular}{cccc}
\hline Pendekatan & Kelas & Skor Rata-Rata & Kategori \\
\hline Saintifik & Eksperimen I & 3,0 & Cenderung Positif \\
ELPSA & Eksperimen II & 3,1 & Cenderung Positif \\
Open-Ended & Eksperimen III & 3,0 & Cenderung Positif \\
\hline
\end{tabular}

\section{Komparasi keefektifan secara inferensial}

Indikator keefektifan yang dibandingkan pada analisis inferensial adalah hasil belajar siswa, skor minat belajar siswa dan respons siswa. Setelah dilakukan uji normalitas sebagai uji prasyarat pada indikator keefektifan yang dimaksud, hasil belajar, minat belajar dan respons berdistribusi normal maka selanjutnya dilakukan uji homogenitas untuk mengetahui kehomogenan varians dari populasi ke tiga pendekatan. Setelah menuhi syarat homogenitas.Selanjutnya dilakukan pengujian pada, postest dengan uji ano diperoleh nilai statistik $F=1,486$ dan nilai $p=33$, karena nila $>$ dari $\alpha=0,05$ maka di terima dan i tolak, gain dengan uji an diperoleh nilai stik $F=1,628$ dan nilai $p=0,203$, karena nilai $p>$ dari $\alpha$ $=0,05$ maka di terima dan Hi tolak, ketuntasan klasikal dengan uji maan dua pro diperoleh diterima dan di tolak, minat belajar dengan uji an diperoleh nilai 
statistik $F=1,245$ dan nilai $p=0,298$, ka nilai $p>$ dari $=0,05$ maka di terima dan i tolak, respons dengan uji anova diroleh nilai stati $F=1,397$ dan nilai $p$ $=0,254$, karena nilai $p>$ dari $\alpha=0,05$ maka di terima dan i tolak. Sehingga secara inferensial tidak signifikan artinya hipotesis mayor 4 tidak teruji kebenarannya sehingga dapat disimpulkan bahwa tidak terdapat perbedaan keefektifan pendekatan ELPSA, Saintifik dan Open-Ended setting Kooperatif Tipe STAD dalam pembelajaran matematika pada kelas VII SMP Negeri Akreditasi A di Kota Makassar.

\section{Pembahasan}

\section{Keefektifan Pendekatan Saintifik}

Berdasarkan hasil penelitian pada aspek keterlaksanaan pembelajaran pendekatan Saintifik setting Kooperatif Tipe STAD sudah terlaksana dengan baik (skor rata-rata) untuk tiga pertemuan 2,95, seperti yang dijelaskan pada hasil penelitian bahwa terdapat aspek-aspek yang masih belum optimal artinya masih ada beberapa aspek yang belum terlaksana sesuai yang diharapkan. hasil tes siswa terhadap hasil belajar pada penerapan pendekatan Saintifik setting Kooperatif Tipe STAD diperoleh rata-rata pretest 42,9 yang berarti kemampuan siswa sebelum penerapan pendekatan Saintifik masih berada pada kategori sangat rendah, hasil pengamatan dua observer terhadap aktivitas siswa di dalam kelompok pada pendekatan Saintifik setting Kooperatif Tipe STAD menunjukkan bahwa dari ke 7 aspek yang diamati, hasil pengamatan dua observer terhadap minat belajar siswa di dalam kelompok pada pendekatan Saintifik setting Kooperatif Tipe STAD menunjukkan bahwa dari ke 3 aspek yang diamati, hasil pengumpulan angket respons siswa terhadap pendekatan pembelajaran Saintifik setting Kooperatif Tipe STAD menunjukkan bahwa dari ke 11 aspek yang di respons berada pada kategori "cenderung positif" sehingga dapat dikatakan bahwa respons siswa pada penerapan pembelajaran pendekatan Saintifik setting Kooperatif Tipe STAD belum optimal, artinya masih ada beberapa aspek yang belum tercapai dari respons siswa terhadap pembelajaran yang diharapkan.

\section{Keefektifan Pendekatan ELPSA}

Berdasarkan hasil penelitian pada aspek keterlaksanaan pembelajaran pendekatan ELPSA setting Kooperatif Tipe STAD sudah terlaksana dengan baik (skor rata-rata) untuk tiga pertemuan 2,98, seperti yang dijelaskan pada hasil penelitian bahwa terdapat aspek-aspek yang masih belum optimal artinya masih ada beberapa aspek yang belum terlaksana sesuai yang diharapkan, hasil tes siswa terhadap hasil belajar pada penerapan pendekatan ELPSA setting Kooperatif Tipe STAD diperoleh rata-rata pretest 42,6 yang berarti kemampuan siswa sebelum penerapan pendekatan ELPSA masih berada pada kategori sangat rendah, hasil pengamatan dua observer terhadap aktivitas siswa di dalam kelompok pada pendekatan ELPSA setting Kooperatif Tipe STAD 
menunjukkan bahwa dari ke 7 aspek yang diamati, hasil pengamatan dua observer terhadap minat belajar siswa di dalam kelompok pada pendekatan ELPSA setting Kooperatif Tipe STAD menunjukkan bahwa dari ke 3 aspek yang diamati, hasil pengumpulan angket respons siswa terhadap pendekatan pembelajaran ELPSA setting Kooperatif Tipe STAD menunjukkan bahwa dari ke 11 aspek yang di respons berada pada kategori "cenderung positif" sehingga dapat dikatakan bahwa respons siswa pada penerapan pembelajaran pendekatan ELPSA setting Kooperatif Tipe STAD belum optimal, artinya masih ada beberapa aspek yang belum tercapai dari respons siswa terhadap pembelajaran yang diharapkan.

\section{Keefektifan Pendekatan Open-Ended}

Berdasarkan hasil penelitian pada aspek keterlaksanaan pembelajaran pendekatan Open-Ended setting Kooperatif Tipe STAD sudah terlaksana dengan sangat baik (skor rata-rata) untuk tiga pertemuan 3,10, seperti yang dijelaskan pada hasil penelitian bahwa terdapat aspek-aspek yang masih belum optimal artinya masih ada beberapa aspek yang belum terlaksana sesuai yang diharapkan, hasil pengamatan dua observer terhadap aktivitas siswa di dalam kelompok pada pendekatan Open-Ended setting Kooperatif Tipe STAD menunjukkan bahwa dari ke 7 aspek yang diamati, hasil pengamatan dua observer terhadap minat belajar siswa di dalam kelompok pada pendekatan Open-Ended setting Kooperatif Tipe STAD menunjukkan bahwa dari ke 3 aspek yang diamati, hasil pengumpulan angket respons siswa terhadap pendekatan pembelajaran Open-Ended setting Kooperatif Tipe STAD menunjukkan bahwa dari ke 11 aspek yang di respons berada pada kategori "cenderung positif" sehingga dapat dikatakan bahwa respons siswa pada penerapan pembelajaran pendekatan Open-Ended setting Kooperatif Tipe STAD belum optimal, artinya masih ada beberapa aspek yang belum tercapai dari respons siswa terhadap pembelajaran yang diharapkan.

\section{Komparasi Keefektifan Secara Deskriptif Hasil Belajar}

Berdasarkan hasil penelitian, penerapan pendekatan Saintifik, ELPSA dan Open-Ended mencapai kriteria keefektifan dan dapat disimpulkan bahwa jika di tinjau dari indikator hasil belajar maka secara holistik hasil belajar siswa pada kelas yang diajar dengan menggunakan pendekatan ELPSA lebih efektif dibandingkan dengan dua pendekatan lainnya yaitu pendekatan Saintifik dan Open-Ended, serta pendekatan Open-Ended lebih efektif dari pada pendekatan Saintifik. Secara parsial keefektifan secara holistik ini juga berlaku pada sub-sub indikator posttest, gain dan ketuntasan klasikal. Hal yang sedikit berbeda adalah bahwa kondisi awal kemampuan siswa untuk materi perbandingan (pretest), kelas yang diajar dengan pendekatan Saintifik memperoleh skor rata-rata pretest tertinggi kemudian pendekatan ELPSA dan Open-Ended. 


\begin{abstract}
Aktivitas
Berdasarkan hasil penelitian, perbedaan aktivitas siswa dari setiap penerapan pendekatan, baik pendekatan Saintifik, ELPSA dan Open-Ended itu di karenakan kondisi siswa didalam kelas berasal dari latar belakang yang berbeda dari tiga sekolah pada penerapan pendekatan pembelajaran dan hal itu juga yang mempengaruhi aktivitasi siswa didalam kelas, namun dapat dilihat bahwa pencapaian skor aktivitas siswa dari penerapan pendekatan Saintifik, ELPSA dan Open-Ended memang belum optimal artinya masih ada aspek aktivitas yang belum mencapai kriteria yang di harapkan, akan tetapi pencapain skor aktivitas siswa dari penerapan pendekatan Saintifik, ELPSA dan Open-Ended sudah berada pada kategori baik, sehingga dapat disimpulkan bahwa aktivitas siswa pada kelas yang diajar dengan menggunakan pendekatan ELPSA sama efektif dengan Open-Ended serta pendekatan ELPSA dan Open-Ended lebih efektif dari pada pendekatan Saintifik.
\end{abstract}

\title{
Minat Belajar
}

Berdasarkan hasil penelitian minat belajar siswa, dari penerapan beberapa pendekatan baik pendekatan Saintifik, ELPSA dan Open-Ended itu di karenakan kondisi siswa didalam kelas memiliki minat yang berbeda dalam artian tidak sama, setelah di wawancarai beberapa siswa menjawab saya senang dengan materi perbandingan, saya tidak senang dengan materi perbandingan, bahkan ada siswa yang memang sering menerapkan konsep perbandingan didalam kehidupan sehari-hari dan alasan-alasan tersebutlah yang melatarbelakangi perbedaan minat belajar siswa setiap sekolah dari penerapan pendekatan Saintifik, ELPSA dan Open-Ended, namun dapat dilihat bahwa pencapaian skor minat belajar siswa dari penerapan pendekatan Saintifik, ELPSA dan Open-Ended memang belum optimal artinya masih ada aspek minat belajar yang belum mencapai kriteria yang di harapkan, akan tetapi pencapain skor minat belajar siswa dari penerapan pendekatan Saintifik, ELPSA dan Open-Ended sudah berada pada kategori tinggi. sehingga dapat disimpulkan bahwa aktivitas siswa pada kelas yang diajar dengan menggunakan pendekatan ELPSA sama efektif dengan Open-Ended serta pendekatan ELPSA dan Open-Ended lebih efektif dari pada pendekatan Saintifik.

\section{Respons}

Berdasarkan hasil angket respons siswa, secara keseluruhan memberi respons siswa cenderung positif terhadap pembelajaran. Pada pembelajaran pendekatan Saintifik 11 aspek yang direspons dengan perolehan respons siswa telah memenuhi kriteria keefektifan yaitu rata-rata respons siswa berapa pada kategori $\geq 2,4$. Pada pembelajaran pendekatan ELPSA 11 aspek yang direspons dengan perolehan respons siswa telah memenuhi kriteria keefektifan yaitu rata-rata respons siswa berapa pada kategori $\geq 2,4$. Kemudian pada pembelajaran pendekatan Open-Ended 11 aspek yang direspons dengan perolehan 
respons siswa telah memenuhi kriteria keefektifan yaitu rata-rata respons siswa berapa pada kategori $\geq 2,4$. Sehingga disimpulkan bahwa respons siswa pada kelas yang diajar dengan pendekatan ELPSA lebih efektif dibandingkan dengan dua pendekatan lainnya yaitu pendekatan Saintifik dan Open-Ended, serta pendekatan Saintifik sama efektif dari pada pendekatan Open-Ended.

\section{Komparasi Keefektifan Secara Inferensial}

\section{Hipotesis mayor 1}

Sesuai dengan hipotesis penelitian, diperoleh dari hasil analisis bahwa penerapan pendekatan Saintifik setting kooperatif Tipe STAD efektif sehingga hipotesis mayor 1 yang di ukur dari keefektifan hasil belajar siswa, minat belajar siswa dan respons siswa teruji kebenarannya. Setelah melakukan pengujian pada nilai posttest dan gain ternormalisasi dengan menggunakan uji one sample test, diperoleh bahwa $\mathrm{H}_{1}$ diterima dan $\mathrm{H}_{0}$ ditolak dengan demikian pada pembelajaran pendekatan Saintifik posttets siswa dan gain ternormalisasi siswa itu efektif. Persentase ketuntasan klasikal siswa di uji dengan uji proporsi. Dari hasil uji proporsi yang dilakukan ternyata $\mathrm{H}_{0}$ diterima dan $\mathrm{H}_{1}$ ditolak. Namun, walaupun demikian masih dapat disimpulkan bahwa secara inferensial hasil belajar matematika siswa pada kelas yang diajar melalui penerapan pendekatan Saintifik setting Kooperatif Tipe STAD di SMP Negeri Akreditasi A Kota Makassar lebih dari $84 \%$. Hal ini disebabkan karena pada uji proporsi yang dilakukan di atas memiliki jumlah sampel yang kecil jadi kemungkinan untuk menolak $\mathrm{H}_{\mathrm{O}}$ sangat kecil. Minat belajar siswa di uji dengan uji one sample test. Dari hasil uji one sample test yang dilakukan bahwa $\mathrm{H}_{1}$ diterima dan $\mathrm{H}_{0}$ ditolak artinya minat belajar siswa dari penerapan pembelajaran pendekatan Saintifik efektif, sedangkan untuk respons siswa di uji dengan uji one sample test. Dari hasil uji one sample test yang dilakukan bahwa $\mathrm{H}_{1}$ diterima dan $\mathrm{H}_{0}$ ditolak artinya respons siswa dari penerapan pembelajaran pendekatan Saintifik efektif.

\section{Hipotesis mayor 2}

Sesuai dengan hipotesis penelitian, diperoleh dari hasil analisis bahwa penerapan pendekatan ELPSA setting kooperatif Tipe STAD efektif sehingga hipotesis mayor 2 yang di ukur dari keefektifan hasil belajar siswa, minat belajar siswa dan respons siswa teruji kebenarannya. Setelah melakukan pengujian pada nilai posttest dan gain ternormalisasi dengan menggunakan uji one sample test, diperoleh bahwa $\mathrm{H}_{1}$ diterima dan $\mathrm{H}_{0}$ ditolak dengan demikian pada pembelajaran pendekatan ELPSA posttets siswa dan gain ternormalisasi siswa itu efektif. Persentase ketuntasan klasikal siswa di uji dengan uji proporsi. Dari hasil uji proporsi yang dilakukan ternyata $\mathrm{H}_{0}$ diterima dan $\mathrm{H}_{1}$ ditolak. Namun, walaupun demikian masih dapat disimpulkan bahwa secara inferensial hasil belajar matematika siswa pada kelas yang diajar melalui penerapan pendekatan ELPSA setting Kooperatif Tipe STAD di SMP Negeri Akreditasi A Kota Makassar lebih dari $84 \%$. Hal ini disebabkan karena pada uji proporsi yang 
dilakukan di atas memiliki jumlah sampel yang kecil jadi kemungkinan untuk menolak $\mathrm{H}_{\mathrm{O}}$ sangat kecil. Minat belajar siswa di uji dengan uji one sample test. Dari hasil uji one sample test yang dilakukan bahwa $\mathrm{H}_{1}$ diterima dan $\mathrm{H}_{0}$ ditolak artinya minat belajar siswa dari penerapan pembelajaran pendekatan ELPSA efektif, sedangkan untuk respons siswa di uji dengan uji one sample test. Dari hasil uji one sample test yang dilakukan bahwa $\mathrm{H}_{1}$ diterima dan $\mathrm{H}_{0}$ ditolak artinya respons siswa dari penerapan pembelajaran pendekatan ELPSA efektif.

\section{Hipotesis mayor 3}

Sesuai dengan hipotesis penelitian, diperoleh dari hasil analisis bahwa penerapan pendekatan Open-Ended setting kooperatif Tipe STAD efektif sehingga hipotesis mayor 2 yang di ukur dari keefektifan hasil belajar siswa, minat belajar siswa dan respons siswa teruji kebenarannya. Setelah melakukan pengujian pada nilai posttest dan gain ternormalisasi dengan menggunakan uji one sample test, diperoleh bahwa $\mathrm{H}_{1}$ diterima dan $\mathrm{H}_{0}$ ditolak dengan demikian pada pembelajaran pendekatan Open-Ended posttets siswa dan gain ternormalisasi siswa itu efektif. Persentase ketuntasan klasikal siswa di uji dengan uji proporsi. Dari hasil uji proporsi yang dilakukan ternyata $\mathrm{H}_{0}$ diterima dan $\mathrm{H}_{1}$ ditolak. Namun, walaupun demikian masih dapat disimpulkan bahwa secara inferensial hasil belajar matematika siswa pada kelas yang diajar melalui penerapan pendekatan Open-Ended setting Kooperatif Tipe STAD di SMP Negeri Akreditasi A Kota Makassar lebih dari 84\%. Hal ini disebabkan karena pada uji proporsi yang dilakukan di atas memiliki jumlah sampel yang kecil jadi kemungkinan untuk menolak $\mathrm{H}_{\mathrm{O}}$ sangat kecil. Minat belajar siswa di uji dengan uji one sample test. Dari hasil uji one sample test yang dilakukan bahwa $\mathrm{H}_{1}$ diterima dan $\mathrm{H}_{0}$ ditolak artinya minat belajar siswa dari penerapan pembelajaran pendekatan Open-Ended efektif, sedangkan untuk respons siswa di uji dengan uji one sample test. Dari hasil uji one sample test yang dilakukan bahwa $\mathrm{H} 1$ diterima dan $\mathrm{H}_{0}$ ditolak artinya respons siswa dari penerapan pembelajaran pendekatan Open-Ended efektif.

\section{Hipotesisi mayor 4}

Sesuai dengan hipotesis penelitian, diperoleh dari hasil analisis bahwa tidak terdapat perbedaan hasil belajar siswa terhadap pembelajaran pendekatan Saintifik, ELPSA dan Open-Ended sehingga hipotesis mayor 4 tidak teruji kebenarannya. Karena tidak terdapat perbedaan maka tidak perlu dilakukan uji lanjut, artinya apa, penerapan pendekatan saintik, ELPSA dan Open-Ended yang dilihat dari indikator keefektifan hasil belajar siswa, minat belajar siswa dan respons siswa itu hasilnya sama. Setelah mengkompairing posttest dan gain ternormalisasi pada ketiga pendekatan dengan menggunakan uji anova, diperoleh bahwa $\mathrm{H}_{0}$ diterima dan $\mathrm{H}_{1}$ ditolak dengan demikian pada pembelajaran pendekatan Saintifik, ELPSA dan Open-Ended tidak terdapat perbedaan posttets 
siswa dan gain ternormalisasi siswa. Komparasi persentase ketuntasan kalsikal siswa digunakan uji kesamaan dua proporsi. Dari hasil uji kesamaan dua proporsi yang dilakukan ternyata $\mathrm{H}_{0}$ diterima dan $\mathrm{H}_{1}$ ditolak artinya bahwa persentase ketuntasan klasikal siswa dengan penerapan pembelajaran pendekatan Saintifik, ELPSA dan Open-Ended itu sama atau tidak terdapat perbedaan. Komparasi minat belajar siswa digunakan uji anova. Dari hasil uji anova yang dilakukan ternyata $\mathrm{H}_{0}$ diterima dan $\mathrm{H}_{1}$ ditolak artinya tidak terdapat perbedaan minat belajar siswa dari penerapan pembelajaran pendekatan Saintifik, ELPSA dan Open-Ended, sedangkan pada komparasi respons siswa digunakan uji anova. Dari hasil uji anova yang dilakukan ternyata $\mathrm{H}_{0}$ diterima dan $\mathrm{H}_{1}$ juga ditolak artinya tidak terdapat perbedaan respons siswa dari penerapan pembelajaran pendekatan Saintifik, ELPSA dan Open-Ended.

\section{SIMPULAN DAN SARAN}

\section{Simpulan}

Berdasarkan rumusan masalah, tujuan penelitian dan hasil penelitian serta pembahasan yang diperoleh, maka pada bagian ini disajikan simpulan dari hasil yang diperoleh: (1) Pembelajaran dengan pendekatan Saintifik setting Kooperatif Tipe STAD efektif dalam pembelajaran matematika kelas VII SMP Negeri Akreditasi A di Kota Makassar. (2) Pembelajaran dengan pendekatan ELPSA setting Kooperatif Tipe STAD efektif dalam pembelajaran matematika kelas VII SMP Negeri Akreditasi A di Kota Makassar. (3) Pembelajaran dengan pendekatan Open-Ended setting Kooperatif Tipe STAD efektif dalam pembelajaran matematika kelas VII SMP Negeri Akreditasi A di Kota Makassar. (4) Tidak terdapat perbedaan keefektifan pendekatan Saintifik, ELPSA dan Open-Ended secara inferensial, namun secara deskriptif terdapat perbedaan keefektifan setelah penerapan pendekatan pada kelas VII SMP Negeri Akreditas A di Kota Makassar.

\section{Saran}

Berdasarkan hasil penelitian yang diperoleh, dapat dikemukakan bebarapa saran sebagai berikut. (1) Bagi calon peneliti yang ingin melanjutkan penelitian ini agar membuat kegiatan pembelajaran sesuai dengan jumlah pertemuan yang dilakukan disekolah. (2) Agar pengembangan modul matematika setting pembelajaran kooperatif tipe TPS ini lebih sempurna kiranya calon peneliti memperhatikan betul keterkaitan antara masalah yang ada pada uaraian materi dengan latihan kerja siswa. (3) Modul pembelajaran matematika setting kooperatif tipe think pair share (TPS) yang dihasilkan pada penelitian ini hanya diujicobakan pada satu kelas. Hanya uji coba ini yang dijadikan sebagai dasar pertimbangan dalam melakukan revisi modul yang telah dikembangkan. Oleh karena itu untuk memperoleh hasil yang lebih baik disarankan untuk melakukan ujicoba pada skala yang lebih luas. 


\section{DAFTAR PUSTAKA}

Afgani. 2014. Pendekatan Open-Ended dalam Pembelajaran Matematika. (http://file.upi.edu/Direktori/FPMIPA/JUR, diakses 08 Agustus 2016).

Akib, I. 2016. The description of relationship between mathematics charasteristic and bugis culture values. Global Journal of Pure and Applied Mathematics, 12(4), 2765-2776

Nasiruddin Az.zahra, Hamzah Upu, Abdul Rahman. 2012. Developing Learning Packages Of Cooperative Based Model Of Jigsaw Type On The Topic Of Biodiversity In Grade X. Math Education. Makassar: July. 2012.

Cheriani, Mahmud, A., Tahmir, S., Manda, D., \& Dirawan, G. D. 2015. Problem-based learning-buginese cultural knowledge model-case study: Teaching mathematics at junior high school. International Education Studies, 8(4), 104-110. doi:10.5539/ies.v8n4p104

Lowrie, T. \& Patahudin, S. M. 2015. ELPSA: Kerangka Kerja untuk Merancang Pembelajaran Matematika. Jurnal Didaktik Matematika, (Online), Vol.2, No.1 (http://jurnal.unsyiah.ac.id, Diakses 8 Agustus 2016).

Ningsih, 2015. Pengaruh Pembelajaran Saintifik Setting Kooperatif Tipe STAD Terhadap Hasil Belajar Matematika Siswa kelas VII SMP Negeri 6 Watampone. Tesis tidak diterbitkan. Makassar: Program Pascasarjana Universitas Negeri Makassar.

Nisbet, J, 1985. Changing Views On Ability. In Entwistle, $N$ (ed), New Directions In Education Psycology I Learning And Teaching (39-44). London: The Falmer Press.

Nurhidayah, Usman Mulbar, Asdar .2015. Pengaruh Penerapan Model Pembelajaran INSTAD (Inquiry-STAD) Terhadap Motivasi

dan Kemampuan Pemecahan Masalah Matematika Peserta Didik Kelas VII SMPN 5 Wonomulyo Kabupaten Polewali Mandar. Jurnal Pepatzdu. Vol 9, No. 1, Makassar: Mei. 93-94, 2015

Nurlidia. 2015. Komparasi Keefektifan Pendekatan Saintifik, Problem Solving Dan Open-Ended Setting Discovery Learning Dalam Pembelajaran Matematika Materi Lingkaran Di Kelas VIII SMP Negeri 2 Sinjai Timur. Tesis tidak diterbitkan. Makassar: Program Pascasarjana Universitas Negeri Makassar.

Sugiyono. 2016. Statistika Untuk Penelitian. Bandung: Penerbit Alfabeta.

Syarifuddin. 2016. Keefektifan Pendekatan ELPSA dengan Setting Kooperatif dalam Pembelajaran Matematika Materi Bangun Ruang Sisi Datar pada kelas VIII SMPN 4 Binamu Kabupaten Jeneponto. Tesi tidak diterbitkan. Makassar:Program Pascasarjana Universitas Negeri Makassar 